\title{
Voice of Jacob Hand of Esau: Appraising the Role of Chief Executives and Party Leaders in Impeachment Processes in Nigeria
}

\author{
Fatai Ayisa Olasupo \\ Department of Local Governme Nt Studies, Faculty of Administration, Obafemi Awolowo University, \\ Ile-Ife, Nigeria \\ Email: faolasupo@yahoo.com
}

Received 9 September 2013; revised 11 October 2013; accepted 13 November 2013

Copyright (C) 2014 by author and Scientific Research Publishing Inc. This work is licensed under the Creative Commons Attribution International License (CC BY). http://creativecommons.org/licenses/by/4.0/ (c) (i) Open Access

\begin{abstract}
As a three-tier government that Nigeria is, three legislatures exist and all have the impeachment powers that have been grossly abused: The National Assembly, the state assembly and the local legislative council. A close study of their activities, regarding impeachment duties, shows a consistent bias in the ways they exercise these powers particularly at the National and state levels. Prior to fourth republic only once did states (Kaduna and Kano) assemblies have gut to impeach a governor and a deputy Governor-Alhaji Balarabe Musa and Bibi Faruk-since 1979 when Nigeria began the practice of Presidential system of government. In the present Fourth Republic not less than five Governors have been impeached, although three of them had been reversed by judicial review. At the national level, it has always been a mere threat against the chief executive but not so with the leadership of the National Assembly. It is even worse at the local level. It is curious however, to find that the victims of true impeachment powers have always been the powerless deputies and the leaderships of the legislatures at the various levels of government. Even in these, the process through which these powers are exercised is often characterised by corruption of different categories such as bribery and coercion leading to perversion of due process to attain the nefarious goals. The study shows that often those behind the impeachments are the chief executives and party leaders who goad the members of the legislatures to embark on such constitutional but perverted acts.
\end{abstract}

\section{Keywords}

Impeachment; Process; Chief Executives; Party Leaders; Legislature 


\section{Introduction}

Other than the electoral process, impeachment is the main means by which elected chief executives, the leaderships of the legislatures and the chief judges of courts could be removed from their respective offices in Nigeria. The responsibility for this, under the presidential system of government which Nigeria has adopted since 1979, is vested in the various legislatures at all levels of government-federal, state and local. The reality of the exercise of this power by the legislature, however, shows consistent pattern of extraneous forces dictating and shaping the course and patterns of the impeachment processes. Accordingly, whereas threats of impeachment abound at all levels of government, the chief executives are rarely actually impeached while other "junior" officials become the victims of impeachment. Generally, since the impeachment of Governor Balarabe Musa of Kaduna State in 1980 impeachment of chief executives rarely succeed and in this regard the Legislatures have remained toothless bull dogs.

On the contrary, legislative houses have, with ease, changed their own leaderships. The same thing can be said of the deputy chief executives who are no more than toothless bull dogs since the latter have no constitutional responsibilities beyond the ones assigned to them by their chief executives.

The observation above raises the critical question of whether the legislatures are truly independent of the chief executives and the judiciary as envisaged by the constitution in the performance of their constitutional duties, particularly those relating to impeachment matters. Why is it difficult to impeach the chief executives while the less powerful Deputy Governors, Speakers, Deputy Speakers, Vice/Deputy Chairmen (of local governments) are easily removed from offices? What are the behind-the-scenes undercurrents of the impeachment processes in Nigeria? What roles do the chief executives themselves, party leaders and other extra-parliamentary individuals and bodies play in the success or otherwise of impeachment exercises in Nigeria? In essence, what are the extraconstitutional factors that shape the patterns and processes of impeachment? These and similar questions are the concern of this paper, which seeks to examining the political undercurrents of the impeachment processes in Nigeria.

\section{Definition of Terms}

Four terms that need clarification or definition here are the "Chief Executives”, "Party Leaders”, "Extraneous bodies" and "Impeachment".

Chief Executives at all the levels of government in Nigeria include the President/Vice-President, State Governor/Deputy-Governor and Chairman/Vice-Chairman at the local level (Fagbadebo, 2007; Olasupo, 2011).

Party leaders: This refers to leadership of the various political parties, especially the ruling ones at the Local, State and Federal levels. The following officials: Party Chairman, Zonal Chairman, State Chairman, Local Chairman and their Secretaries are very critical in the running of their various political parties at all the levels of government.

Extraneous bodies: This includes individuals and bodies that are not members of parliament but do exercise considerable leverage in moderating debates and other activities of the legislatures at various levels of government, especially the former military Heads of State, Governors and, of course, the Godfathers among other minor ones.

Impeachment: Osa Iyinbo sees it as "a tool for change in the hands of the legislators". According to him, while ballot is the "only effective weapon available to the people, impeachment is the only effective weapon the legislators posses to remove the Chief Executives. Mike Ikhariale further elaborated that as vote of No Confidence is a weapon of change of the Chief Executives by the legislators under the Westminster parliamentary system, so is impeachment the weapon of change in the hands of the legislators under presidential system of government. Thus, according to Mike Ikhariale, impeachment "denotes a constitutional process designed to remove a president who has been found guilty of provable acts which, in the thinking of the legislators, amounted to "gross misconduct" (Ikhariale, 2002; Iyinbo, 2007). According to Edwin Madunagu on the other hand, Whereas sections of the press give the false impression that to impeach means "to remove from office", the real meaning of to impeach is "to accuse a public official before an appropriate tribunal of misconduct in office; to challenge the credibility of; to bring an accusation against; to call into question; to cast an imputation upon; to call into account” (Madunagu, 2003). Finally, to Pini Jason In the book: Power of Congress, published by the Congressional Quarterly Inc; impeachment is described as "perhaps the most awesome though the least used power of Congress". "The publication went further to describe impeachment as "a political action, couched in 
legal terminology, directed against a ranking official of the federal government”. In the United States, the House of Representative is the prosecutor. The Senate chamber is the courtroom; and the Senate is the judge and jury, said the book. The final penalty is removal from office and disqualification from further office. There is no appeal! (Jason, 2006)

\section{Impeachment}

At the inception, monarchy was the only legitimate form of government ever known to man. However, its inadequacies, among others—autocracy, despotism and nepotism—led mankind to invent other forms of modern government not in one person or institutions but in many persons or institutions. Two of such modern systems are parliamentary and presidential systems of government with each spearheaded by Britain and the United States of America respectively. To prevent these two new modern systems of government from going the ways of monarchy, a number of checks and balances were placed on their paths. One, the people are empowered to vote in and vote out the chief executives and the members of the legislatures periodically (Wood, 1992). Two, the two new governmental systems were separated into three distinct branches, against the prevailing situation of embodiment of these three in one people under monarchical system of government. While the separated organs of government are expected to cooperate with one another in the process of good governance, they are as well expected to act as checks against one another. Thirdly and finally, is the power to remove the chief executive forcefully-impeachment or passing a vote of no confidence, as in the case of parliamentary system of government.

Thus, there are two ways of removing the chief executives_-direct and indirect removals. Direct removal has to do with when the electorates vote out the chief executive for lack of performance while the indirect removal of the chief executive is when the legislature whose members were directly elected by the electorates removes the chief executive on behalf of the people. In short, in impeaching the chief executive, the legislature does so, on behalf of the people. In exercising this power, the legislature is not absolutely on its own as it is checked by the judiciary which the constitution vests with the power to appoint the members of the panel of investigators (Azinge, 2002). Additionally, the chief executive or his deputy also has a way of checking the legislature by "defending himself in person and represented by lawyers of his own choice before the investigating committee" obtaining the services of a lawyer at the hearing (Akinsanya \& Ayoade, 2005).

Describing the nature of impeachment, Azinge states that "In England, parliament saw impeachment as a powerful weapon of fighting the lords and the executives. It was a means of checking the excesses or despotism from those quarters" (Azinge, 2002). "In America" on the other hand, according to him, "the adoption of the separation of power secured a permanent place for impeachment in the Constitution” (Azinge, 2002). For him therefore, the significance of impeachment "lies in the possibility of instituting proceedings against top public officers who ordinarily are constitutionally immune from prosecution” (Azinge, 2002). Since Nigeria adopted parliamentary system of government in the first republic and is now operating presidential system of government, all the constitutions within these periods made provision for impeachment clauses.

\subsection{Impeachment Procedures}

\subsubsection{Governor or Deputy Governor}

These (impeachment procedures) need elaboration and illumination because most of the impeachment frauds are woven around them. The processes that constitutionally have to be followed in toeing impeachment procedures are so cumbersome that they may take not less than three months before a chief executive is successfully removed. However, what operates today is removing chief executive in less than a week's time. In some places, Speakers of the House of Assembly are removed within a day. Or how does one explain the case of Imo State House of Assembly that produced three Speakers in less than a fortnight. The first Speaker of the House that was validly elected was Noel Aguocha Chukwukadibia. Upon his removal as Speaker, his Deputy, Ernest Ibejiako stepped in. In less than a week "reign" of Noel, another Speaker, Nnaemeka Maduagu stepped in (Aja, 2001). This is a classic example of abuse of due process. There are many of such abuses in the impeachment gale that is currently rocking every level of governments in Nigeria.

Now, what are the constitutionally stipulated procedures that legislatures must follow when embarking on impeachment of Chief executives or leaderships of the legislatures? The 1999 Constitution is clear on how a Governor or the Deputy of a state may be removed from office if found "guilty of gross misconduct in the per- 
formance of the functions of his office" (S. 188(1)). This section provides that "a notice of any allegation in writing" shall be "signed by not less than one-third of the members of the House of the Assembly" detailing the specific particulars of such "gross misconduct" with the accused Governor or Deputy Governor having the opportunity to respond thereto. The notice is presented to the Speaker. This is stage one.

Stage two is that the Speaker of the House of Assembly shall, within seven days of the receipt of the notice, cause a copy of the notice to be served on the holder of the office and on each member of the House of Assembly, and shall also cause any statement made in reply to the allegation by the holder of the office, to be served on each member of the House of Assembly.

The third stage is that within 14 days of the presentation of the notice to the speaker of the House of Assembly, the House shall resolve by way of motion whether or not to investigate the said allegations.

The fourth and final stage is that, according to subsection (4) thereof, "A motion of the House of Assembly that the allegation be investigated shall not be declared as having been passed unless it is supported by the votes of not less than two-thirds majority of all the members of the House of Assembly” (Iyinbo, 2007).

The fifth one is that the Speaker of the House shall, within seven days of the passing of the motion (supported by two-thirds majority of all the members of the House of Assembly) that the allegation be investigated, caused the allegation to be investigated by a Committee of seven persons.

Sixth, that the seven persons, approve by the House of Assembly, are in the opinion of the Speaker, of "high integrity, not being members of any public service, legislative house or political party" to conduct the investigation.

Seventh, that the Governor or Deputy Governor shall have the right to defend himself in person and be represented by lawyers of his own choice before the Investigation Committee.

Eight that the Investigations Committee shall: 1) have such powers and exercise its functions in accordance with such procedures as may be prescribed by the House of Assembly; and 2) report its findings to the House of Assembly within three months.

Nine that the impeachment proceedings shall cease if the Investigations Committee reports to the House of Assembly that the allegation has not been proved.

Ten, that if the Investigations Committee reports that the allegation against the Governor or Deputy Governor has been proved, the House shall, within fourteen days of the receipt of the Report, consider the Report (Akinsanya \& Ayoade, 2005).

Eleventh that the Governor or Deputy Governor stands automatically removed from office the very day that the Report of the Investigations Committee is adopted by a resolution of the House of Assembly supported by not less than two-thirds majority of all its members.

\subsubsection{Chairman or Vice-Chairman}

The laws of Osun State of Nigeria volume 4 states procedure by which the Chairman of a Local Government or Vice-Chairman of a Local Government could be removed.

Ten items that indicate how any of these public officers could be removed are listed thus:

1) The Chairman or Vice-Chairman may be removed from office in accordance with the provision of this section.

2) Whenever a notice of any allegation in writing signed by not less than one-half of the members of the council is presented to the Governor stating that the holder of such office is guilty of misconduct in the performance of the functions of his office detailed particulars of which shall be specified, the Governor shall within 7 days of the receipt of the notice cause a copy thereof to be served on the holder of the office and on each member of the Local Government Council and shall also cause any statement made in reply to the allegation by the holder of the office to be served on each member of the Council.

3) Within 14 days of the presentation of the notice (whether or not any statement was made by the holder of the office in reply to the allegation contained in the notice) the Local Government Council shall resolve by motion without any debate whether or not the allegation shall be investigated.

4) Within 7 days of the passing of a motion under the foregoing provision of this section, the Chief Judge shall constitute a panel of three judges to investigate the allegation and report to the Governor within 14 days.

5) The holder of an office whose conduct is being investigated under this section shall have the right to defend himself in person or be represented before the Investigating Panel by a legal practitioner of his own choice.

6) Where, having considered the report, the Governor decides that the holder of the office is guilty of the 
allegation, he shall so inform the Local Government Council concerned: Provided that where the Governor decides that the allegation has not been proved, no further proceeding shall be taken in respect of the matter, and the Governor shall inform the Local Government Council concerned accordingly.

7) On receiving the copy of the decision of the governor that the Chairman is guilty of the allegation, the Local Government Council shall resolve that the Chairman be removed from Office, and give the notice of such a resolution to the Governor for his action: Provided however that the resolution of the Council that the Chairman be so removed shall not be declared as having been passed unless it is supported by the votes of not less than two-thirds majority of all the members of the Local Government Council.

8) On receiving the notice of the resolution of the Council, the Governor shall declare the holder of the office as having been removed from office from the date of passing the resolution and shall thereafter take appropriate step under the Law to swear in a successor.

9)In this section "misconduct" means a breach of Oath of Allegiance or Oath of Office or a breach of the provisions of the Constitution or a misconduct of such nature as amounts to bribery or corruption or false declaration of assets and liabilities or conviction for treason or treasonable felony.

10) Nothing in this section shall preclude the Governor if he is satisfied after due investigation, from suspending any officer to which this section applies for a period not exceeding three (3) months, provided that such a decision is supported by a resolution of the House of Assembly (Osun-State).

\subsubsection{Chief Judge of a State}

The Chief Justice of Nigeria or the Chief Judge of a State against whom an allegation of inability to misconduct or contravention of the code of conduct has been made under this section shall be entitled to defend himself in person or by a Legal practitioner of his own choice before the investigating panel..."

1) The Investigation panel shall at the conclusion of the investigation in respect of the Chief Justice of Nigeria or the Chief Judge of a State submit the report of it's finding to the president of the Senate or Speaker of the House of Assembly who shall immediately submit the said report to the Senate or the House of Assembly of the State for consideration as the case may require.

2) The Senate or the House of assembly of a state shall within a period of not more than 60 days from the date of the receipt thereof consider such report.

3) If the report is considered and confirmed by an address supported by 2/3rd majority of the Senate or house of Assembly of the State, the President of the Senate or Speaker of the House of Assembly shall send the decision thereof to the President or Governor... who shall thereupon remove the Chief Justice of Nigeria or the Chief Judge of a state from office...” (Majebi, 2009).

A violation of any or more of these procedures (at any level of government) is enough to declare the exercise futile and therefore null and void. It is also important to note that any activity of the House done outside the House of Assembly or done at midnight where members of the public may not have the opportunity of watching the proceeding of the House is also fraud and therefore unconstitutional. In Nigeria today, hardly could any impeachment, at any level of government, be found to have passed this acid test; since, to quote Osa Iyinbo, just as "Justice delayed is justice denied, so is justice dispensed at the speed of light, at ungodly hours and in controversial circumstances" (Iyinbo, 2007). An important observation that also needs to be made here is the interplay of all the branches of government at each level of government in the impeachment procedure at each level. With regards to impeachment procedure of the Local chief executive or his deputy, the Governor of a state concerned is actively involved. This is an attestation to the fact that local governments should truly be decentralized bodies of state governments rather than the prevailing situation in which federal government contests the control of local governments with the states.

\subsection{Impeachment at the National Level Presidency}

To date, impeachment games in Nigeria straddle the Executives (at the state and local level), the Senate, the House of Representatives, House of Assemblies and the local legislative councils. While it has been a mere weapon of threat against the executives at the national level, it has been very, very effective in changing the Senate presidents as well as the Speakers of the House of Representatives. However, in whatever situation, be it threat or actual, it has often been accompanied by a lot of theatrics that put the nation at a boiling point.

Starting with the impeachment of the President, only twice was Chief Olusegun Obasanjo threatened with 
impeachment. The first was in August 2002 and the second one was that of April 2005 (Ugbolue, 2002; Anza, 2005). None of these threats lacked sufficient theatricals underpinned by accusations and counter accusations between the executive and the legislature on one hand, and their various supporters on the other. When the President was alleged with impeachable offences in 2002, not only the executive was rattled by this but also the entire nation. This was more so because of the international dimension of the impeachment notice. When did it become a norm for the legislature of a particular country to notify international community that it wants to impeach her President? For, Nigerian national legislators were once found "sent impeachment notice to foreign embassies and urged the international community to desist from further dealings with the embattled president" (Ugbolue, 2002). Before then, the president had been threatened to resign within two weeks or "risked being impeached" (Ugbolue, 2002).

After the catalogue of offences, which the House of Representative accused the President to have committed, it moved a motion that states: "That by reason of monumental inadequacies, ineptitude, persistent disrespect for the rule of law and the obvious corruption being perpetrated in the Presidency which exposes Mr. President, Chief Olusegun Obasanjo is hereby advised to resign honourably as President and Commander-in-Chief of the Armed Forces of the Federal Republic of Nigeria within two weeks from the date of the motion" (Ugbolue, 2002). The President reacted to this by summoning his council of ministers and top security chiefs "about well-funded plot to truncate civil rule". He counter-alleged that "huge sums of money were shared out to selected members of the National Assembly to move against the government". Following the President and his executive reactions were those of his party and one opposition party from the zone where the President came from. His party, PDP and its chairman, Chief Audu Ogbe, threatened to move against any party member who dared move the motion (Ugbolue, 2002).

In 2005, another impeachment move was commenced by the House of Representatives when on April 17, 2005 it decided to set up a 15 man committee to fine-tune and finalise the impeachment process of the President (Anza, 2005). The theatricals here include putting 19 impeachment offences against the President together by one single person, Idris Nadabo, who was also a member of the House of Representatives. Besides, he had earlier singularly collected the signatures of members in support of the impeachment move against the constitutional procedure of opening a hard cover register with proper inscription for the collection of signatures of those members in support of the impeachment (Anza, 2005). Because of the improper procedure bothering on lack of due process, the House stepped in and set up a committee to follow normal procedure which then opened a new register for collection of impeachment signatures of willing members. House leader, Abdul Ningi, headed the committee which was an existing one earlier set up to compile constitutional breaches against the President. He was also the one expected to liaise with the Senate on the issue and report back to the House. Some days after, two principal officers of the House, Abike Dabiri, chairman, House Committee on Media and Publicity and Abba Ojomo, chairman, House committee on Information were separately interviewed on how much signatures had been collected so far. While Ojomo stated that 240 members of the House had already signed the register, Dabiri, said just 199. To be noted here is the fact that Ojomo is a member of the ruling party while Dabiri is from one of the two opposition parties, Alliance for Democracy (AD) and All Nigerian Peoples Party (ANPP). Specifically, Dabiri is from AD which is an opposition party from the geographical zone of the President.

The discrepancies in both impeachment moves-those of August 2002 and April 2005 to be specific, and many others that did not see the lights of the day-against the President led to the failure and collapse of the impeachment moves against him. More so was the unseriousness and triviality of the House in both impeachment cases. Less than 24 hours after the motion for the impeachment was moved in 2002, the House could not form a quorum to perform their constitutional duties (Ugbolue, 2002). This gave rise to various insinuations and charges that "only when members of the National Assembly are broke or they have an axe to grind with the president that they think of an impeachment. "As soon as they are 'talked to', they drop the impeachment moves" (Anza, 2005). The Daily Trust editorial of Wednesday, April 18, 2005 put it this way: "Nigerians are outraged that the only times our honourable members seem to wake up to their legislative responsibilities are when the executive tinker with their personal benefits. It is at such periods that our lawmakers realise that the president has expropriated powers beyond his constitutional limits”.

\subsection{Senate}

It is at the Senate level that impeachment theatrics are at their best because of the principal figures that are at 
play. When the first Senate president under the present fourth republic was to be elected, the President, Chief Olusegun Obasanjo and his Vice, Alhaji Abubakar Atiku supported different candidates: Senators Evan Enwerem and Chuba Okadigbo respectively even though there had been a "signed understanding between President Obasanjo and Vice-President and leaders of the party" that Chuba Okadigbo should be supported to become the Senate President. But the "understanding" was later betrayed and Evan Enwerem became the Senate President (Asaju, 2001). To sustain the betrayal, Chuba Okadigbo said that "a night before the election, Obasanjo moved against him with what is known in legislative circle as GMG or Ghana Must Go bags, an euphemism for jute bags used in bribing people with cash" (Asaju, 2001). Soon, the camp of the Vice-President dig deep to excavate impeachment evidences against Senator Enwerem. Among other impeachment offences against Enwerem were certificate forgery, names change and date of birth. So, "On November 8, 1999, shortly after, Enwerem was toppled and Okadigbo took over as Senate President. No sooner had Okadigbo become Senate President than he began to accuse the President of seeking his removal because of his (Okadigbo) insistence "that the legislature be allowed to play its role as a check on the executive". He also charged the President for a plot to replace him "with a lame duck president who will do his (President) bidding (Aiyetan, 2001). As the most scholarly and colourful Senate President ever produced up to date, he laid bare the crass procedural process that was used to remove him. Beyond this, and emboldened by these redoubtable evidences of massive procedural subversion of the impeachment procedure, he fought hard for rectitude.

\subsection{House of Representative}

House of Representatives that the constitution designated to play prominent role, with regards to initiating impeachment of the President, is also a case study in impeachment theatricals not only of that of the President but also of its own leadership. When the first Speaker of the House of Representatives, Alhaji Salisu Ibrahim was found guilty of certificate forgery and perjury in the process, the House resolved to remove him but in a gentle manner. Being a loyal member of the ruling party, he was advised to resign honourably and precluded from prosecution, against what the law says. Ordinarily, the offences committed by him were punishable ones but because he had financially invested so much in the party and was also to become the Speaker, the first one at that in the fourth republic, the government and party leaders decided to overlook the punitive aspect of his criminal offences (Olasupo, 2005).

Another Speaker of the House that was also found guilty of impeachable offences was the first female Speaker of the House. It is public knowledge that the former President of the country, Chief Olusegun Obasanjo and the leadership of his party (PDP) played prominent role in the installation of the first female Speaker, Madam Patricia Olubunmi Etteh. On being found guilty of impeachable offences of contract inflation and embezzlement, particularly "for breach of due process in the award of contracts" worth N628 million "for the renovation of her official residence and that of her deputy, Babangida Nguroje” (Nwikwor, 2008). A panel, David Idoko panel, was set up to investigate her (Utomwen, 2007). The panel found her guilty and asked her to resign honourably because she is from the ruling party. When she resisted, impeachment move was made against her but her backer also stepped in to prevent her removal. The first person to step in to shield Etteh was her Senate colleague who is also the president of the Senate, Senator David Mark. He was reported to have "prevailed on Idoko to ensure that he uses his office as Chairman to present a report that would not have any serious effect on Etteh. To lay the foundation for this, Mark, sources said, actually recommended Idoko for the Chairmanship position. Mark and Idoko are from the same Senatorial district in Benue state and from the same Idoma ethnic background" (Utomwen, 2007).

Following the Senate president was the then Chairman of the party, Col. Ahmadu Ali. Ali was said to have "threatened to personally spearhead the recall of any recalcitrant member bent on removing the Speaker". At a meeting he was said to have held with PDP leaders in the House, at Protea Hotel, Abuja, Ali was reported to have said "I am leaving Etteh in your hands; the party is leaving her with you and if she is impeached, I will personally lead the fight for your recall” (Utomwen, 2007).

However, within the House is a group of legislators who tagged themselves as "Integrity Group” (IG). They carved for themselves the role of upholding the integrity and credibility of the House. According to them, "The House of Representatives should rise above primordial sentiments and proceed to impeach her in order to restore the credibility of the National Assembly. Thereafter, they contended, Mrs. Etteh should be handed over to the ICPC or EFCC for prosecution without any further delay. After all, Senator Adolphus Wabara”, a former Senate 
President, "and his indicted colleagues are standing trial for lesser offence. What is good for the goose is good for the gander" (Utomwen, 2007). Compromise was reached thereafter as Madam Speaker and her deputy resigned honourably, though they were forced to do so on October 30, 2007 (Nwikwor, 2008). And the House also overlooked the punishable aspects of their impeachment offences.

\subsection{Reasons for Executive Interference}

The critical question to ask at this point is why is the executive at the national level interested in who becomes Senate President and Speaker of the House of Representatives respectively as against the normal way of allowing the two principal officers of the National Assembly emerge through genuine democratic process? The national executive, since the inception of this fourth republic, has been meddling and undermining the independence of the parliament; why is this so? The leaderships of the parliament (Senate and House of Representatives) are elected and dismissed in a questionable and dubious circumstances; what is/are the reason(s) of the executive for these?

One of the possible reasons why National Executive is inexorably meddling in the affairs of the legislature is the prolong stay of the military in governance. Throughout the military regimes in this country, as Alade Fawole puts it: "Unlike the executive and judicial arms, which have remained permanently in existence since independence, the legislature is the one that is always suspended under military rule" (Fawole, 2007). The "Military dictators" he went on "have often combined the legislative and executive powers in their ruling organs with the implications that the legislature is always a new phenomenon every time civilians return to power, and that newly elected representatives have no continuous precedence to follow or fall back upon” The military cultures of combining legislative and executive powers have thus permeated every strata of the society. This is more so because the first president of the country in the present fourth republic happened to be a retired military General who was also former military Head of State. Some executive and congressional members are also retired military officers. A retired general, General Abdulkarim Adisa, provided the reason for this, according to him, for now, “...We need a dictator” (Aiyetan, 2001).

The second major reason is the phenomenon of Godfathers. Who are they and what danger do they constitute to the state? Providing answers to these, former Governor of Anambra state, Chimaroke Nnamani, defines godfather as:

"Strictly... there is a self-seeking individual out there to use the government for his own purposes. The cost of this incidence is enormous to the state as what obtains is that when the incumbent godson is at pains to satisfy the whims and caprices of the godfather among other competing demands on the scarce resources of the government, the interest of the larger number is savagely undermined" (Ogunleye, 2003).

Former President Olusegun Obadanjo was once a victim of this. According to him (President Obasanjo) "some godfathers in the North had wanted him to sign an agreement granting some concessions to the North, in exchange for their support for his presidential ambitions” (Ogunleye, 2003).

\subsection{Governors}

To date, not less than five Governors have been impeached by their various Houses of Assembly but none stood the test of time because of the circumvention of constitutional procedure for doing so. The first governor impeached was Diepreye Alamieyeseigha (Bayelsa state); followed by Rashidi Ladoja (Oyo); Ayodele Fayose (Ekiti); Joshua Dariye (Plateau) and Peter Obi (of Anambra state) (Akinkuotu, 2007). They were impeached alright but courts reinstated them for lack of proper way of doing so. In the second republic, impeachment was sparingly used and only once was a Governor and a Deputy Governor impeached even though this was not also without its flaws but minimal. While the Deputy of Governor to Alhaji Abubakar Rimi of Kano state was impeached, it was the Governor of Kaduna state that was similarly impeached. According to the first impeached governor of Kaduna State, Alhaji Balarabe Musa:

"My removal is different in so many ways. The disregard for constitutional process is there. This is at a much higher level than during my time. Secondly, during my time, there was nothing criminal. But now, all the allegations are criminal. They are based on stealing and corruption. During my time, there was some restraint” (Ashaka, 2006). 
One interesting thing about impeachment palaver of governors in the fourth republic is the existence of "two governors": the de facto ones and the de jure. The de jure governors are godfathers that sponsor the de facto ones (godsons). The conflict of interest between the godfathers and the godsons always lead to godfathers sponsoring the impeachment of the recalcitrant godsons. This in turn leads to the governors wanting to pocket principal officers of the legislature who could be used by godfathers, by any means possible. In the process, massive state resources as well as private ones especially by the de jure governors are deployed to bribe the members of the legislature and its leadership. The end result of these is acquisition of dictatorial powers that make the governors and their godfathers dictatorial at the state level just as the President at the national level. As the godfathers wants to take control of governance and award of contracts in the states so do the governors wants to take control of the executive and the legislature and, possibly the godfathers. As a matter of fact, "in many states, the choices of speakers are largely influenced by the governors” (Aiyetan, 2001).

States with the de facto (governors or godsons) and the de jure (godfathers) that competed for the control of their state legislatures for impeaching one another are Oyo: between Rashidi Ladoja and Lamidi Adedibu; Kwara: Muhammed Alabi Lawal and Dr. Abubakar Olusola Saraki; Anambra: Chinwoke Mbadinuju and Emeka Offor; Enugu: Chimaroke Nnamani and Jim Nwobodo; River state: Peter Odili and Marshal Harry; Borno state: Malam Kachala and Senator Ali Sherif; Plateau state: Solomon Lar (former Chairman of PDP) and Joshua Dariye. The state governors and their godfathers, in their quest for absolute dictatorship also seek for national godfathers in person of either the President, his vice or powerful traditional rulers. Such was the case in Anambra state where President Obasanjo backed Offor and the Vice-President backed Governor Mbadinuju (Adebanjo, 2001). When the president was unwilling to hand over power to his deputy, Alhaji Atiku Abubakar, was found to have "sent many emissaries, including traditional rulers, from almost all the geographical areas of the country to the president to no avail" (Ojewale, 2005). A dramatic impeachment palaver, never witnessed in any democratic nation all over the world was the case of Governor Chris Ngige of Anambra. When his godfather, Chris Uba, could not muster enough support in the legislature to impeach him, a civilian coup, engineered by the police, had to kidnap him. Public and international outcry forced the police to return him to where they kidnapped him.

\subsection{Deputy Governors}

Deputy Governors successfully impeached, even if under dubious procedure, included Abubakar Argungu (Kebbi State); Chief Abiodun Aluko (Ekiti); Paul Alabi (of Ekiti but survived impeachment move against him); Iyiola Omisore (Osun). Other states where Deputy Governors were impeached are Abia, Akwa Ibom Taraba states, among others (Akinrosoye \& Mukwuzi, 2005). In Lagos state, impeachment moves against two Deputy Governors: Bucknor-Akerele and Pedro were hardly concluded before they resigned from office. Impeachment procedural defects here included spending less than three days to investigate accused Deputy Governors. While that of Chief Abiodun Aluko took up to three days, that of Akwa Ibom lasted only one day (Akinrosoye \& Mukwuzi, 2005). Part of the theatrics here was the invitation of thugs, in Osun state, to police the State House of Assembly since the police appeared to be sympathetic to the Deputy Governor who was believed to have godfathers at the national level. The first time the law makers in Osun attempted to impeach him, the Deputy Governor was smarter enough to bring in thugs to invade the "house and chased out the legislators" (Owolabi, 2002). The latest drama over impeachment of a Deputy Governor is currently playing out in Bauchi state. The Governor of the state, Isa Yuguda, and his Deputy, Mohammed Gadi, were elected on the ticket of ANPP. Recently, the Governor got married to one of the daughters of President Yar'Adua, necessitating the governor to switch over to PDP, the party of his new Godfather, and also his new father in-law. The Governor did but the Deputy Governor has so far refused, leading to brandishing of impeachment sword before him. According to the supporters of the converted Governor: "The deputy ought to be a gentleman and either joins in the Peoples Democratic Party (PDP) or be politically rubbished" (Tsenzughul, 2009). The major cause of friction between the Governors and their Deputies is lack of insubordination on one hand, and lack of constitutional roles for them (Deputy Governors) on the other. Under the current constitution, the status of Deputy Governors, as Chukwuemeka Ezeife who was also a former governor, puts it, is "spare-tyres" (Adeyemo, 2002).

Deputy Governors also have godfathers, perhaps borne out of the fear that if they run counter to their bosses, there should be somebody to protect them. Former Deputy Governor of Osun State, Iyiola Omisore, is a good example here. When he fell out with the then Governor of the State, Bisi Akande, presidency became his refuge. 
When Chief Abiodun Aluko also fell out with Ayo Fayose, a factional leader of PDP in his state, Chief Ojo Falegan, became his godfather (Akinrosoye \& Mukwuzi, 2005).

\subsection{Speakers}

The impeachment of the Speakers or leaderships of the Houses of Assembly across the country has been the most dramatic of all the theatricals. Being the ones (legislatures) empowered by the constitution to impeach or remove the leadership of virtually all the three arms of government: executive, legislative and judiciary, upon found guilty of gross misconduct, the drama of removing its own leadership is always tension soaked. In Imo state for example, we have examples of one week speakers. Noel Aguocha Chukwukadibia was first to be validly elected as speaker but within a short while, he was toppled. Deputy majority leader, Ernest Ibejiako mounted the saddle. "Barely one week into Ibejiako's reign, however, another change of guards threw up Nnaemeka Maduagu as the substantive speaker” (Aja, 2001). In Anambra State in 2006, the Governor of the state, Peter Obi, was impeached at dawn. The coup leader, Mike Balonwu and his troops staged the coup at dawn, about 7.30 am, when it was carried out. The deputy Governor, Virginia Etiaba who the coup leader asked to step into the shoes of Obi initially declined to be sworn in but the pressure from external quarters, specifically Abuja, melted her resolve and she agreed to be sworned in the following day, thereby becoming the first female governor in Nigeria (Obasi, 2006). In the same state recently, "less than four hours after election of the Speaker of the House of Assembly, Anayo Nnebe, he survived impeachment by the whiskers (Onu, 2008).

The latest bizarre cases of impeachments are those of the Lagos and Niger states House of Assemblies deputy speaker and the Speaker respectively. Both victims, (Mrs Funmi Tejuosho (Deputy Speaker Lagos State House of Assembly) and the Speaker of Niger State House of Assembly were not only refused notification nor were they on seat before their cases were considered and determined. Mrs. Funmi Tejuosho was in London for a short break since the House was on recess. In her absence the House was horridly convened for the purpose of her removal which was done with despatch. The Speaker of the Niger State House of Assembly on the other hand had gone to inspect constituency project when the House formed plenary session headed by his, Mohammed Alkali, deputy, Bashir Lokogoma and got him removed and replaced instantly. His offence was "sluggish style of leadership. The House also believes that he was not apt enough thus "We had to act the way we did to move the state forward" (Orintunsin, 2009). Barely a week after the new Speaker was elected, in a letter he wrote to the House, he resigned his office citing one, lack of atmosphere of peace and harmony in conducting the affairs of the House and two, the need for "collective duty of all legislators to uphold our mandates and to allow dialogue and understanding to guide our roles in fulfilling our promises to the electorate" (Laleye, 2009). However, it was later discovered that what is happening in the House is not an affair of the House alone as former military rulers (Generals Babangida and Abdul Salami Abubakar) are found to be the unseen drummers for the dancing legislators (Laleye, 2009).

Another important drama in conducting legislative matter, particularly impeachment, is conducting such serious legislative matters outside the four walls of the legislative house. To impeach the Speaker of the Enugu House of Assembly, the camp that wanted him removed shifted their deliberations to Abuja only to come back to Enugu later to effect the removal of the unwanted speaker. "On arrival at the assembly complex, the legislatures could not gain entry into the premises as the gate was securely locked with chain. Angered by the development, they hired the services of a wielder who cut the keys under the watchful eyes of the police" (Aham, 2002). "Traditional rulers in Enugu soon joined the drama by asking the two feuding factions of the Enugu state House of Assembly not to hold further sitting within the next two months (Obe, 2002). These are some of the bizarre and undemocratic circumstances under which, what are supposed to be sacred duties of impeachments, were carried out.

Godfathers and godsons are always the ones who engage themselves in battle over enslavement of the Speakers. Most members of the Houses of Assembly are always sponsored by the forces who wish to control them and they become tools of enslavement once they get to the House, not only to their sponsors alone but also the governors who crave their absolute loyalties to them. To get their loyalties, governors provide them with contract awards through which they snatch their loyalties away from their sponsors. Prior to all these, forces that sponsor most of them, look for academic imbeciles who do not have minds of their own and could therefore not question most of their nefarious moves. Amidst these dual loyalties, they (Speakers) loose control of their conscience and therefore become unable to perform the role of checking the excesses of neither the governors nor act inde- 
pendently of the godfathers.

Vaulting ambitions of most Speakers who want to be governors, Deputies who wanted to move higher and on and on are also responsible for current gale of impeachments at all levels of government. Case studies here include Ekiti and Plateau States. In both states, both the governors and their deputies were impeached to pave ways for their respective Speakers to become Acting Governors (Nwosu, 2006). In Ogun state, when the female Speaker, Mrs. Titi Oseni was impeached, ordinarily and legally, the deputy Speaker ought to have moved up the lather but he was bypassed to bring in Tunji Egbetokun, an ordinary floor member (Olayeni, 2009). To do this, they go beyond their brief of impeaching the governors, to also impeach their deputies and then create illegal Acting Governor post, which in the process, dare the electorate, the judiciary and Nigerians at large. This in turn attracted counter reaction from the Federal government that slammed declaration of state of emergency on states where this is the case. So far, only Ekiti and Plateau States have been found to attract this king federal interventions in the governance of the state.

The executive and party leaders' involvement in impeachments at sub-national institutions manifested itself recently in Kaduna State House of Assembly. To remove the Speaker of the House, Usman Gangara, on the day of the impeachment and while the impeachment procedure was going on; a police helicopter hovered over the Assembly complex while armed police secured the surroundings of the House (Binniyat, 2013). The House members that impeached the Speaker "were less than 23 required under section 92 (c) of the 1999 Constitution by four members who reportedly sat without the mace. In short, 19 members of the House out of the total number of 34, short of constitutionally required number of two third majorities, which is 23, removed the Speaker. This explains why the House had to be besieged by armed air and ground forces.

To date, Speakers improperly impeached or forced to resign in the current fourth republic include Chief (Mrs.) Margaret Icheen (first female Speaker in Nigeria (Benue); Ayo Agbomuerin, Victor Akninwe, his deputy, and six other principal officers (Ondo); Chief Abiodun Aluko (Ekiti), Femi Bamisile (Ekiti), Noel Aguocha Chukwukadibia (Imo); Ernest Ibejiako (Imo); Nnaemeka Maduagu (Imo); Abel Chukwu (Enugu), Emeka Nnamani (Deputy Speaker Enugu) (Albert, 2008).

\subsection{Chief Judge}

State legislatures are also empowered by the constitution to impeach erring state chief judge. According to Nnamdi Uchendu, under section 292 paragraph A item 2 of the 1999 constitution "the governor shall remove the CJ upon and address supported by two third majority of the House of Assembly praying that he be so removed for either inability to discharge the functions of his office or for misconduct" (Okonkwo, 2006).

It was under this provision that legislators in Abia state removed the state chief judge, Kalu Amah. C.O Enweremadu, representing Isiala Ngwa constituency had moved a motion for the removal of Kalu from office and was supported by two-third of the members of the State Assembly. As usual, the governor of the state, party leaders and other interested parties stepped in to prevail on the Assembly members for their respective different interests. There were those who wanted the legislators to back-down and there were those who upheld the position of the Assembly members. Still, there were those who sat on the fence. Ekiti state was another state where the Chief Judge of the state (Justice Kayode Bamisile) had to be impeached before impeaching the governor. The latest is Kwara state where a female Judge, Justice Raliat Elelu-Habeeb was recently removed by the State House of Assembly on order from Governor Bukola Saraki. All these had precedent in Justice Kalu Anyah who was removed by Borno State House of Assembly in the Second Republic.

However, the purported impeachments of the CJs without the recommendation of the National Judicial Council (NJC) are said to be usurpation of the authority of that council and are to that extent unconstitutional. According to Chief Gani Fawehinmi, "the NJC headed by the Chief Justice of Nigeria was constitutionally empowered to discipline the CJ. He said that, by suspending the Chief Judge, even if the Chief CJs had acted improperly, the lawmakers went beyond their powers under the 1999 Constitution of the Federal Republic of Nigeria. He explained that under section 292(1) (a) (11) of the constitution, a chief judge can be removed from office by the governor upon the address of the state House of Assembly supported by two-thirds of the members (Fabowale, Bamidele, Adeoti, \& Raheem, 2006). Chief Justice Belgore supported this when he said "whatever the Ekiti lawmakers were doing, suspending the state Chief judge, Kayode Bamisile, was illegal” (Nwosu, 2006).

A new dimension in the case of state legislature's power to impeach the state Chief judge was uncovered in Plateau state. This power went beyond impeachment of Chief Judge to imposition of a retired Chief Judge. Pla- 
teau state House of Assembly craved for this when it imposed retired Justice Sambo as the new state's Chief Judge. But Plateau State branch of the Nigerian Bar Association, (NBA) promptly rejected the re-instatement (Agboola, 2007).

\subsection{Local Government Chairmen}

Some Local government chairmen have also suffered from dubious impeachment procedures. A handbook on Local Government administration in Nigeria that preceded 1999 constitution stated clearly the process and procedure expected to be followed in impeaching a Chairman or Vice-Chairman. According to the book, "A Chairman or Vice-Chairman of Local Government who is found guilty of gross misconduct, within the context of the existing laws of the Federation, could be impeached by the Local Government Council” (Agboola, 2007). It went on to say that "Impeachment is an instrument of last resort designed to enhance public probity and accountability and shall not be employed frivolously, selfishly or as a tool for personal vendetta or political victimization" (Agboola, 2007). Finally it concluded that "No Chairman or Vice-Chairman of Local Government shall be deemed to have been impeached until the basic conditions stipulated in the Constitution of the Federal Republic of Nigeria, and other relevant laws, as they relate to the impeachment process, have been fully satisfied" (Agboola, 2007).

One of such chairmen, impeached by bypassing due process was Chief Dupe Ogundiminegha, the executive chairman of Ose Local Government area of Ondo State under All Nigerian Peoples Party (ANPP). The impeached chairman was accused of high handedness and malpractice. But the chairman "explained that his relationship with both councillors and members of the executive council had been cordial since his assumption of office, he noted that prior to the session of the legislative house where he was impeached, he was never invited for discussion". "Neither was I tried by any panel. It was therefore a big surprise only to hear in the news that I have been removed" (Olabisi).

Another Chairman of a Local government impeached by suspension was George Osikorobia, the executive chairman of Ughelli North Local Government. His offences were one, "refusal of Osikorobia to render income and expenditure accounts to the legislative house as prescribed by section 70(5) of the local government law, 1999 of Delta State. Two, "violating section 61 (1 and 4) of the local government law". Three, that "in spite of resolutions, invitations, reminders and summon on him by the house which the chairman ignored" (Umanah, 2000). As a result of all these "the suspension was carried out by six principal officers of the house, against five other members of the 11 member legislature. This is however a simple majority rather than two-third majority that the constitution stipulates.

At the local level could also be found local tyrants wanting to pocket the legislatures and prevent democratic decisions at the cabinet meetings. In Epe local government of Lagos state for instance, the chairman of the council found guilty of highhandedness against the legislature had to be suspended by the state governor. The legislators accused him of "authoritarian style" in the way he took "over the jobs of supervisory councillors and running the council like his personal household" (Aiyetan, 2001). Similar accusation of highhandedness was levelled against Gilbert Nnaji, chairman of Enugu East Local Government in Enugu state. In his own case "he took highhandedness to a new height when he ordered deductions from the salaries of workers in the public health department of the council”.

Some Monarchs (who are tyrants) also regularly meddle into the affairs of Local governments in their areas of jurisdiction. Example of such cases is the case of the Monarch of Auchi, Alhaji Aliru Momoh, who intervened in the process of removing the House Leader of Etsako West Local Government council, Miss Abibat Yakubu. She was accused of being too close to the Chairman of the council, Mr. Hassan Kadiri, to the extent that she gets "all the favours from him (Chairman) for her to put her colleagues under check (Ogbemudia, 2013). For this, the eleven lawmakers in the council rose against her by unanimously endorsing her impeachment in what looks like preparing the grounds for eventual impeachment of the Chairman too. The Chairman had earlier falling out of favour with other powerful members in the community. One, he is no longer in good terms with $\mathrm{h}$ is deputy, Alhaji Alhassan Idaro, who had publicly slapped the Chairman over money quarrel. Two, he also fell out with his godfather, Otumba Charlton Mogaji, who bank-rolled his electioneering campaign. But the powerful monarch in the community unconstitutionally intervened by summoning the lawmakers to his palace and persuaded them to sheath sword (Ogbemudia, 2013).

Though the constitution made local government the third tier of government, this is so in theory not in practice 
as it is the whipping boy of all the levels of government. Just as the local legislators have powers to impeach the chairman so do the state legislators, the governors and even the President who should have no business meddling in local government affairs.

To date quite a large number of LG chairmen have been removed not by the local legislative bodies but by state legislatures and governors. Kaduna state started it with the removal of $10 \mathrm{LG}$ chairmen. Following Kaduna is Ondo state that has so far removed six LG chairmen : chief Dupe Ogundiminegba (Ose LG); chief Gilbert Adepoju (Ondo East LG); chief Adedayo Adesida (Ondo West LG); chief Siaka Olorunyomi (Odigbo LG); chief Ayeni Olayeye (Okiti pupa LG); and Dr. Francis Ajih (Ese odo). From Osun state the impeached chairmen include Mr. Nathaniel Arabambi (Ayedaade LG); Mr. Adebowale Olaoye (Odo-otin LG). In Oyo state the following chairmen among others were removed: Olujide Solomon Ajao (Ibadan North EastLG); Mr. Afolabi (Kajola LG). Lagos state: Engineer (Otunba) Dele Kuti (Ikorodu LG) was suspended from of office. Others from other parts of the country such as Zamfara, Niger, Kano, Rivers, Enugu,Anambra, Kwara and Akwa Ibom states who were impeached are: Solomon Kogi, Aliu Ikara, Aliu Wara, Smaila Gurijian, Mina Cleve Tende, Sunday Anyanwa, Ben Onyin, Chuks Anah, Etheobi Okpala, Emmanuel Ebe, Opaknte Jackreese, Me. Yakubu Jesse, Ikara Bibis, Alhaji Jibrin Sabo Keana (Olasupo, 2008).

\subsection{Local Government Legislative Council}

As are the cases at the state and national legislatures, leaders of local legislative councils also have their own excessive politicking that result in removal of the leadership. At Nsukka Local Government recently, the leader of Legislative Council, Mr. Dominic Ajibo was improperly removed because the council could not sit to bring this about. When it was time to begin the process of impeaching the leader, the Clerk of the Legislative Council, Mr. Joseph Ugwuanyi ran away with the mace thus preventing members of the council from sitting. However, "the council boss reportedly invited the leader (Ajibo) to his office on Monday and asked him to resign his position in the council (Orji, 2009). The accusation made against the leader of the Legislative Council borders on corruption. The councilors in the area want to know how 2 billion naira accruing to the council from the federal allocation was spent. Last but not the least is the case of Akuku local government area where in one fell swoop, the entire leadership of the council was impeached. However, the chairman of Akuku-Toru local government area of Rivers State, Chief John Briggs, was found to be behind the "masterminding the change in the leadership of the legislative arm of his council"... and for declaring "six councillorship seats vacant". He himself had to be accordingly suspended from office by the state government.

Only in Lagos state has a local legislative council recently demonstrated its independence of the external forces by removing its leader and reinstating him back as well without the interference of the State government or any godfather. "The leader of Ifako-Ijaye Local Government Legislative House in Lagos State, Hon. Niyi Fadare" was impeached on September 8, 2009 (Okwuofo, 2009). Less than a month thereafter, at a plenary session of the council held on $29^{\text {th }}$ September 2009 at the chamber, Iju Areas office, a legislative member, "Hon Babajide Atala, moved the motion that the House revert to the status quo" (Okwuofo, 2009). The motion was supported by Hon. Sesi Davids and Fadare, the pardoned impeached and reinstated legislative leader, thanked his colleagues for their maturity.

\section{Observation and Conclusion}

It is observed that at all levels of government where impeachment is one of the tools for removing elected executives and even appointed officials such as the state Chief Judges, for grave offence(s), the desire to do so as quickly as possible, possibly under less than a minute, is present. Also observed is the fact that no impeachment exercise, especially during this fourth republic, has been successfully carried out, following the due process.

But the constitutional process for carrying out impeachment process is so cumbersome, complex and time wasting that where there is need to save the country from serious political, economic and social anarchy, prolonged process may lead to war especially in a multi-ethnic state like Nigeria. But then this is not to suggest sacrificing due process for expediency.

More than that, Nigeria's political background is such that favoured quick decision making when it comes to the issue of removing elected or appointed official. At independence, Nigeria practised parliamentary system of government that made for quick decision not only in removing the Chief executive through passing a vote of no confidence but also in appointing him or her as well. It should be noted that when civilian administrations also 
misbehaved in 1966 and 1983, quick but unconstitutional means were also adopted in getting rid of them, ditto for military administrations that were most often not trailed by blood. Prior to independence, colonial administration in Nigeria, which is military-like in nature, also favoured quick decision in removing Chief executives. To do this, they co-opted traditional rulers who were autocrats like them to govern the people. But they do not blink twice to remove them (traditional rulers) when there is a serious disagreement between them (colonial authorities and the traditional rulers).

Thus, given this background, it will be too much for one to expect our young and inexperienced legislators in this fourth republic to demonstrate sufficient mastery of impeachment procedure.

Lastly, these gales of impeachments in the country, legally or illegally aside, have their positive sides. First, they have put our political institutions-Executive, Legislature and Judiciary into serious test and show that they are, though latent, potentially workable. Second, they have served as positive way of checking the excesses of not only the executive but also the judiciary. Mere announcement of impeachment move not just alerts the public that there is "fire on the mountain" but also serves as "wake up" call to the executives to watch their rears.

\section{References}

Adebanjo, A. (2001). Deadly Battles in the State: Tired of the Meddling Political Godfathers, Many Governors Strike for Freedom by Taking on Their Former Mentors. Tell of July 9, 23

Adeyemo, W. (2002). Endangered Species: Lagos State deputy governor, Kofoworola Bucknor-Akerele, Resigns Her Position as Some of Her Colleagues Face Testing Time in Their States. Tell of December 30, 48.

Agboola, M. A. (2007). 10 Lawmakers Back out of Fresh Plot to Impeach Dariye. Jos. Friday, May 4. URL: Copy.

Aiyetan, D. (2001). Nigeria’s New Dictators: Nigeria May Have Attained Democratic Rule, But across the Nation, at All Levels of Government, the New Men at the Helm of Affairs Still Carry on the Business of Governance in an Authoritarian Manner Reminiscent of the Long Years of Military Rule. Tell of December 17, 48.

Aham, U. (2002). Controversial Impeachment: Controversy Trails the impeachment of Enugu State House of Assembly speaker, Abel Chukwu. TheNews of August 26, 45.

Aja, U. (2001). A Tale of Two Speakers. Source of December 24, 29.

Akinrosoye, I., \& Mukwuzi, M. (2005). Bitter Impeachment: Chief Abiodun Aluko Is Impeached as Deputy Governor of Ekiti State in Controversial Circumstances. TheNews of October 10, 39.

Akinsanya, A. A., \& Ayoade J. A. A. (2005). Readings in Nigerian Government and Politics (p. 177). Ijebu-Ode, Ogun State: Gratia Associates International.

Akinkuotu, A. (2007). Impeachment, Their Impeachment. Tell of March 26, 5.

Albert, I. O. (2008). Section 4 Appendix. In Y. Yusufu, S. Egwu, U. O. Udenta, T. Lakoju, R. Nwikkwor, O. Olaniyan, B. Eluma, \& T. Oyewo (Eds.), Conflict Tracking Dossier: A Quarterly Review, Issue (pp. 70, 72 and 82). Ibadan: StirlingHorden Publishers LTD.

Anza, P. (2005). Collapse of a Plot: Th1e Impeachment Plot in the House of Representatives against President Olusegun Obasanjo Loses Steam Following High-Level Political Horse Trading. Newswatch of May 30, 22.

Asaju, T. (2001). A Fighter and a Runner. Newswatch of April 30, 28.

Ashaka, K. (2006). Balarabe Musa Warns: One day Obasanjo Will Suspend N. Assembly. 13.

Azinge, E., (2002). Legislative Adjudication: Uses and Abuses. In C. F. Okolocha (Ed.), Issues and Processes in Legislation: With a Forward by Anyim Pious Anyim (p. 166). Benin City: UNIBEN Press.

Binniyat, L. (2013). Confusion in Kaduna over Purported Impeachment of Speaker. Vanguard Newspaper, September 25, 2.

Fabowale, Y., Bamidele, R. Adeoti, A., \& Raheem, T. (2006).

Fagbadebo, O. (2007). Judicial Review of Impeachment procedure: Implication for Democratic Stability in Nigeria. In The Annual Meeting of the International Society of Political Psychology (p. 5). Classical Chinese Garden, Portland, Oregon.

Fawole, A. (2007). National Assembly as Pillar of Democracy. The Westerner of January 21, Back Page.

Federal Republic of Nigeria (1992) Handbook on Local Government Administration (p. 10). Abuja: Office of the VicePresident.

International Society of Political Psychology, Classical Chinese Garden. (Portland, Oregon USA, July 04 2007. Not available. 2009-05-24.

Ikhariale, M. (2002). The Impeachment Myth Versus the Nigerian Reality Nov. http://www.nigerdeltacongress.Com/iarticles/Impeachment_myth_versus_the_nige.ht 
Iyinbo, O. (2007). Nigeria’s Impeachment Saga: Democracy on the Legislature’s Butcher Block.

http://findarticles.com/p/articles/mi-m5QWD/is 1 5/ai n25001269

Jason, P. (2006). The Weighty Side of Impeachment. Vanguard Newspaper of October 31, 5.

Laleye, D. (2009). Niger New Speaker Resigns: Ma'ali Now Speaker. Nigerian Tribune of June 17, 5.

Laleye, D. (2009) IBB Denies Plot to Remove Niger Gov. Nigerian Tribune of June 17, 6.

Madunagu, E. (2003). Impeachment in Nigeria. http://www.nigerdeltacongress.Com/iarticles/Impeachment_in_nigeria.htm

Majebi, E. (2009). http://www.vanguardngr.com/2009/06/26/wanted-a-more-secure-tenure-for-nigerian-judges-2/

Nwikwor, R., (2008). Analysis of Tracked Media Reports in Idasa. In Conflict Tracking Dossier: A Quarterly Review (Issue 9, p. 45). Ibadan: Stirling-Horden Publishers Ltd.

Nwosu, S. (2006). Winners and Loosers Emergency Rule in Ekiti State. Saturday, 21 October 2006, URL: Copy.

Obasi, S. (2006). Coup at Dawn: Peter Obi, Governor of Anambra State Impeached at a Controversial Early Morning Session of the State House of Assembly November 2. Newswatch of November 13, 52.

Obe, E. (2002). Royal Fathers Ban Enugu Assembly from Sitting. The Punch of August 29, 11.

Ogunleye, G. (2003). Godfather Politics and the Drama in Anambra. Saturday Punch of July 9.

Ogbemudia, O. B. (2013). Otaru Saves Council Boss from Impeachment. The Nation on Sunday of November 23, 76.

Ojewale, O. (2005). Atiku's Rough Road to 2007. Tell of October 31, 22.

Olasupo, F. A. (2005). National Question and Politics at the Local Level. In W. O. Alli (Ed.), Political Reform Conference, Federalism and the National Question in Nigeria (p. 142). Nigeria: Nigerian Political Science Association.

Olasupo, F. A. (2009). Due Process Corruption in Public Services in Nigeria: Local Government as a Case Study. In O. Aborisade, \& I. O. Aransi (Eds.), Public Administration in Nigeria (p. 33). Charlotte, NC: Catawba Publishing Company.

Olayeni, K. (2009). Ogun Assembly Mischievous over My Appointment. The Compass of May 17, 15.

Olasupo, F. A. (2011). Power Struggle and Impeachment as Means to an End: Osun State as a Case Study, 1999-2003. In M. O. A. Alabi (Ed.), Unbroken Legacy of Service: Speaker Bello's Twelve Years under Three Administrations in Osun (p. 5). Ilorin: Intellectual Research Institute.

Onu, N. (2008). Plot to Impeach Anambra Speaker Thickens. The Nation of March.

Orintunsin, J. (2009). Niger Speaker Removed over Poor Performance. The Nation of June 10, 9.

Oseheye, O. (2009). Council Leader Reinstated. The Nation of October 5, 12.

Osun State. The Laws of Osun State of Nigeria. Vol. 4 CAPS 68-96 LEG-OSU, (England: Antony Rowe Limited, Bumper Farm, Chippenham, Wiltshire. Authorised by the Government of Osun State of Nigeria to print the Laws of Osun State). 271-272.

Orji, A. (2009). Council in Crisis over Removal of Leader. The Nation of June 10, 8.

Owolabi, Y. (2002). Ige Haunts Omisore. Tell of December 30, 41.

Tsenzughul, A. (2009). Bauchi Deputy Governor Deserves Impeachment: The Deputy Did Not Contest and Win Election, but the Governor Did. It Is Necessary the Deputy Follows His Boss. The Nation of June 24, 6.

Ugbolue, H. (2002). Gunning for the President. The News of August 26, 20.

Umanah, O. (2000). LG Boss Suspended in Delta. Sunday Punch of April 2, 35.

Utomwen, D. (2007). Clinging on Desperately: The Speaker of the House of Representatives, Patricia Olubunmi Etteh Fights Hard to Survive. The News of October 22, 49.

Wood, G. S. (1992). Democracy and the American Revolution. In J. Dunn (Ed.), Democracy the Unfinished Journey 508 BC to 1993 (p. 91). New York: Oxford University Press Inc.

Yishau, O. (2009). Aliu vs Kure: A Battle IBB Could Not Settle: Despite the Intervention of Two Former Heads of State, Ibrahim Babangida and Abdulsalami Abubakar, Niger State Governor Babangida Aliu and His Predecessor, Abdulkadir Kure Sinks Deeper into the Trenches. The Nation of June 19, 9. 